\title{
Temporal dynamics of spectral reflectance and vegetation indices during canola crop cycle in southern Brazil
}

\section{Daniele Gutterres Pinto $^{1^{*}}$ Denise Cybis Fontana ${ }^{1}$ Genei Antonio Dalmago ${ }^{2}$ Gilberto Rocca da Cunha ${ }^{2}$ Elizandro Fochesato ${ }^{3}$ Matheus Boni Vicari ${ }^{4}$ Jorge Alberto de Gouvêa ${ }^{2}$ Anderson Santi ${ }^{2}$}

${ }^{1}$ Departamento de Plantas Forrageiras e Agrometeorologia, Universidade Federal do Rio Grande do Sul (UFRGS), 91540-000, Porto Alegre, RS, Brasil. E-mail: daniele.gutterres@gmail.com. *Corresponding author.

${ }^{2}$ Centro Nacional de Pesquisa de Trigo, Embrapa, Passo Fundo, RS, Brasil.

${ }^{3}$ Departamento de Agronomia, Universidade Alto Vale do Rio do Peixe (UNIARP), Caçador, SC, Brasil.

${ }^{4}$ Departament of Geography, University College London, Londres, Reino Unido.

\begin{abstract}
The objective of this study was to characterize the variability of spectral reflectance and temporal profiles of vegetation indices associated with nitrogen fertilization, crop cycle periods, and weather conditions of the growing season in canola canopies in southern Brazil. An experiment was carried out during the 2013 and 2014 canola growing seasons at EMBRAPA Trigo, Passo Fundo, state of Rio Grande do Sul, Brazil. The experiment was conducted in a randomized block design with four replications. Five doses of nitrogen top dressing were used as treatments: 10, 20, 40, 80, and $160 \mathrm{~kg} \mathrm{ha}^{-1}$. Measurements were obtained with the spectroradiometer positioned above the canopy, to construct spectral reflectance curves for canola and establish temporal profiles for several vegetation indices (SR, NDVI, EVI, SAVI, and GNDVI). In addition, data on shoot dry matter were obtained and phenological stages were determined. The spectral reflectance curves of canola were reported to change with canopy growth and development. Temporal profiles of vegetation indices showed two maximum peaks, one before flowering and other after flowering. The indices SR, NDVI, EVI, SAVI, and GNDVI were able to characterize changes in the canola canopy over time, as a function of phenological phases, weather conditions, and nitrogen fertilization, throughout the development cycle. Plant growth and development, variations in crop management, and environmental conditions affect the spectral response of canola.

Key words: spectroradiometry, nitrogen fertilization, Brassica napus.
\end{abstract}

Dinâmica temporal dos índices da reflectância espectral e índices de vegetação durante o ciclo da cultura de canola no Sul do Brasil

RESUMO: O objetivo deste trabalho foi caracterizar a variabilidade da reflectância espectral e dos perfis temporais dos indices de vegetação de dosséis de canola, associada à adubação nitrogenada, aos periodos do ciclo da cultura e às condições meteorológicas no sul do Brasil. Foi instalado um experimento nas safras de 2013 e 2014, na EMBRAPA Trigo, em Passo Fundo, RS. O delineamento experimental foi de blocos casualizados com quatro repetições. Foram utilizados os tratamentos de cinco doses de nitrogênio em cobertura: 10, 20, 40, 80, 160kg ha-1. Foram realizadas medições com espectrorradiômetro, sobre o dossel, para compor curvas de reflectância espectral da canola e perfis temporais dos índices de vegetação SR, NDVI, EVI, SAVI e GNDVI. Também foram obtidos dados de matéria seca da parte aérea e feitas determinações de fenologia. Verificou-se que as curvas de reflectância espectral da canola mudaram com o crescimento e desenvolvimento do dossel. Os perfis temporais dos índices de vegetação apresentaram dois picos máximos, um antes e outro após o florescimento. Os índices SR, NDVI, EVI, SAVI e GNDVI foram capazes de caracterizar temporalmente as modificações do dossel da canola ao longo do ciclo, em função de fases fenológicas, condições meteorológicas e adubação nitrogenada. O crescimento e desenvolvimento das plantas, as variações de manejo da cultura e as condições ambientais afetam a resposta espectral da canola.

Palavras-chave: espectrorradiometria, adubação nitrogenada, Brassica napus.

\section{INTRODUCTION}

Canola (Brassica napus L. var. oleifera) has become an important crop of economic interest in southern Brazil, as an alternative to winter cereals under crop rotation systems and due to the high oil content of its seeds (TOMM, 2007). The relatively recent introduction of this crop to the agricultural systems of southern Brazil has given rise to a need for specific knowledge on growing conditions in the subtropical climate that predominates in the region. Within this context, monitoring tools are available for use during the growth cycle that allow characterization of growing practices, assessment of variability in growth and development during a specific harvest and between harvests, and prediction of crop yield. Most of the aforementioned variability is associated with local environmental conditions, especially weather conditions, and with crop husbandry practices adopted by growers.

Regarding weather conditions, variability in crop weight and grain yield is largely associated with temperature and water regimes during the 
growing cycle. Agriculture is the most climatedependent economic activity (SENTELHAS, 2009). Among crop husbandry practices, nitrogen fertilization is a major causative factor of variability in leaf area index (LAI) and seed weight and yield, as nitrogen is a nutrient essential to plant growth and development (GRANT \& BAILEY, 1993). When nitrogen is insufficient, canola plants may display slow growth, small leaves, few branches, a thin, open canopy, short flowering time, and low pod numbers (GRANT \& BAILEY, 1993).

Remote sensing techniques, such as vegetation indices, are one of several options available for data generation on canola growing in the Southern Brazilian, state of Rio Grande do Sul. MÜLLER et al. (2009) tested several vegetation indices, derived from spectral data obtained from a canola canopy fertilized with different nitrogen doses, and showed that these indices can be used to predict the green area and dry matter indices.

Vegetation indices have been widely used as indicators of the presence and condition of vegetation, given their association with biophysical parameters such as biomass and leaf area index (PONZONI et al., 2012). The proposal of the vegetation indices more cited in literature, such as normalized difference vegetation index (NDVI) and enhanced vegetation index (EVI), is founded on the antagonistic reflectance response exhibited by vegetation in visible and near-infrared spectral regions; i.e., accumulation of biomass leads to decreased reflectance in the visible region and increased reflectance in the near-infrared region (JENSEN, 2009).

Within this context, the objective of this study was to characterize the variability of spectral reflectance and temporal profiles of vegetation indices associated with nitrogen fertilization, crop cycle periods, and predominating weather conditions during the winter canola growing season in southern Brazil.

\section{MATERIALS AND METHODS}

Experiments were conducted during the 2013 and 2014 harvests at the experimental station of EMBRAPA Trigo, located in Coxilha, state of Rio Grande do Sul, Brazil. The predominant soil of this region is classified as a dark red dystrophic latosol, characterized by being deep to very deep, welldrained, and suitable for annual crops (STRECK et al., 2008). For the purposes of this study, the Hyola 61 canola genotype was seeded in a randomized block design with four replications. Treatments consisted of five doses of nitrogen (urea) top dress: 10, 20, 40, 80, and $160 \mathrm{~kg} \mathrm{ha}^{-1}$. The preceding crops were soybean for the 2013 harvest and common bean for the 2014 harvest. Seeding dates were 22 April 2013 and 29 April 2014. Both experiments used a row spacing of $0.34 \mathrm{~m}$ and a seeding rate to achieve a density of 40 plants $\mathrm{m}^{-2}$. The area of each plot was $127 \mathrm{~m}^{2}$ in 2013 and $60 \mathrm{~m}^{2}$ in 2014 .

After seedling emergence, every 2 weeks, two paired plants representative of each plot were collected for determination of dry matter content. For this purpose, the harvested plants were separated into leaves, stems, flowers, and pods placed in an oven at $60^{\circ} \mathrm{C}$, and dried to a constant weight.

Phenological characterization was performed every 7 days and was based on observation of the main plant development stages, in accordance with the criteria described by IRIARTE \& VALETTI (2008). Phenological stage was deemed to have changed when $50 \%$ of plants in the plot displayed the corresponding phenological characteristic on the main stem. Meteorological data from an automatic weather station installed in the experimental area were used to calculate the climatic water balance for the period April-October, by the method described by THORNTHWAITE \& MATHER (1955). This calculation was based on an available water content (AWC) of $75 \mathrm{~mm}$, which remained constant throughout the cycle. Thermal time were also calculated, using the degree-day method (OMETTO, 1981), considering $5^{\circ} \mathrm{C}$ and $27^{\circ} \mathrm{C}$ as the lower and upper limit base temperatures for canola respectively.

To evaluate the spectral response of canola, canopy reflectance measurements were obtained with a LICOR LI-1800 spectroradiometer (spectral resolution $2 \mathrm{~nm}$ ) in the $350-1100 \mathrm{~nm}$ range. Measurements were taken at a distance of approximately $1 \mathrm{~m}$ above the canopy, resulting in a sample area of $530 \mathrm{~cm}^{-2}$. A barium sulfate $\left(\mathrm{BaSO}_{4}\right)$ plate was used to simulate a Lambertian surface of known reflectance as a reference. Canopy reflectance was calculated as the ratio between canopy and reference surface reflectance. All measurements were obtained with clear, cloudless skies, at approximately 12:00 noon solar time, in an attempt to ensure similar lightning and observation conditions.

One reflectance measurement was obtained from each land plot, on seven days, during the two harvests in which the experiment 
was conducted. These measurements were used to plot mean canopy reflectance curves and calculate the following vegetation indices: simple ratio (SR) (JORDAN, 1969) (Equation 1), NDVI (ROUSE et al., 1973) (Equation 2), EVI (JUSTICE et al., 1998) (Equation 3), soil-adjusted vegetation index (SAVI) (HUETE et al., 1988) (Equation 4), and green normalized difference vegetation index (GNDVI) (GITELSON, 1996) (Equation 5).

$\mathrm{SR}=\rho_{\text {nir }} / \rho_{\mathrm{r}}$

$\operatorname{NDVI}=\left(\rho_{\text {nir }}-\rho_{\mathrm{r}}\right) /\left(\rho_{\text {nir }}+\rho_{\mathrm{r}}\right)$

$\mathrm{EVI}=\mathrm{G}\left(\rho_{\text {nir }}-\rho_{\mathrm{r}}\right) /\left(\mathrm{L}+\rho_{\text {nir }}+\mathrm{C} 1 \rho_{\mathrm{r}}+\mathrm{C} 2 \rho_{\mathrm{b}}\right)$

$\left.\mathrm{SAVI}=\left[\rho_{\text {nir }}-\rho_{\mathrm{r}}\right) /\left(\rho_{\text {nir }}+\rho_{\mathrm{r}}+\mathrm{L}\right)\right](1+\mathrm{L})$

$\operatorname{GNDVI}=\left(\rho_{\text {nir }}-\rho_{\mathrm{g}}\right) /\left(\rho_{\text {nir }}+\rho_{\mathrm{g}}\right)$

Where: $\rho_{\text {nir }}, \rho_{\mathrm{r}}, \rho_{\mathrm{g}}$ and $\rho_{\mathrm{b}}$ are reflectance in the near-infrared, red, green, and blue spectra respectively; $L$ is a constant that minimizes the ground effect $(L=1) ; G$ is the gain factor $(G=2.5)$; and $C 1$ and $C 2$ are adjustment factors to minimize the effect of aerosols in the atmosphere $(C 1=6.5$ and $C 2=7.5$ ).

Spectral bands used for calculation of vegetation indices were made compatible with the band widths and sensitivities of the MODIS (Moderate Resolution Imaging Spectroradiometer) sensor by application of a filter function generated in ENVI $5.0^{\circ}$ software. This procedure aimed to allow future comparisons with orbital data, which is the subject of ongoing investigations. The lower and upper limits of the red, near-infrared, green, and blue bands in the MODIS sensor are 620-670, $841-875$, 545-565, and 459-479nm respectively (ANDERSON et al., 2003).

An analysis of variance was performed for the vegetation indices across different treatments (nitrogen top dress doses) in each year. Means were compared by the Tukey test, at a $5 \%$ significance level $(\mathrm{P} \leq 0.05)$.

\section{RESULTS AND DISCUSSION}

In both harvests, leaf dry matter content increased until the start of the flowering period. From this point onwards, the dry mass of canola becomes mainly composed of stems and pods, whereas leaf dry matter content decreased (Figure $1 \mathrm{~A}$ e $1 \mathrm{~B})$. The mean dry matter partitioning across treatments exhibited a similar pattern in both harvests, and provided evidence of structural changes in the canopy as a function of phenological stages (Figure 1A and 1B). However, differences in cumulative shoot dry matter weight occurred as a result of differences in weather conditions between harvests (Figure 1E and $1 \mathrm{~F}$ ).

During the 2013 harvest, the average air temperature ranged from 12.5 to $17.9^{\circ} \mathrm{C}$, whereas in the 2014 harvest, temperatures were higher, ranging from 13.4 to $18.6^{\circ} \mathrm{C}$. In addition, hidrical excess was observed during the growing cycle; however, this is a common phenomenon during the autumn and winter months in the state of Rio Grande do Sul. The lower temperatures observed in 2013 led to cold acclimation of the plants and, thus, enabled greater vegetative growth than in 2014. Cold acclimation of canola plants consists of a series of physiological, molecular, and biochemical changes that take place in plants exposed to low temperatures (RAPACZ, 1999).

During the vegetative period, plant biomass is composed of stems and leaves. Leaves achieved a peak biomass of $53 \mathrm{~g} \mathrm{~m}^{-2}$ and $189 \mathrm{~g} \mathrm{~m}^{-2}$ in the 2013 and 2014 harvests respectively, at the start of the flowering period, the time during which the LAI is at its highest (JUSTES et al., 2000). At this stage, stem biomass increased as a result of main stem elongation and emergence of secondary stems from axillary buds (THOMAS, 2003). During ripening stage, while leaf dry matter content decreased, pod dry matter accumulation was observed.

The mean reflectance curves for all treatments during the 2013 and 2014 harvests exhibited a typical pattern described by JENSEN (2009) as the "spectral signature of vegetation" and reflected structural changes that took place in the canopy during the growth and development cycle (Figure 1C and 1D).

At the time of the two first measurements in 2013, on 15 July (870 DD) and 30 July (964 DD), reflectance values were the lowest in the visible region and the highest in the near-infrared region. On these dates, plants were in the stem elongation stage, undergoing full-blown vegetative growth. This pattern is due to the preferential absorption of wavelengths in the visible spectrum by photosynthetic pigments, which employed visible-light energy in the photosynthetic process (JENSEN, 2009); whereas, only a small portion of near-infrared 


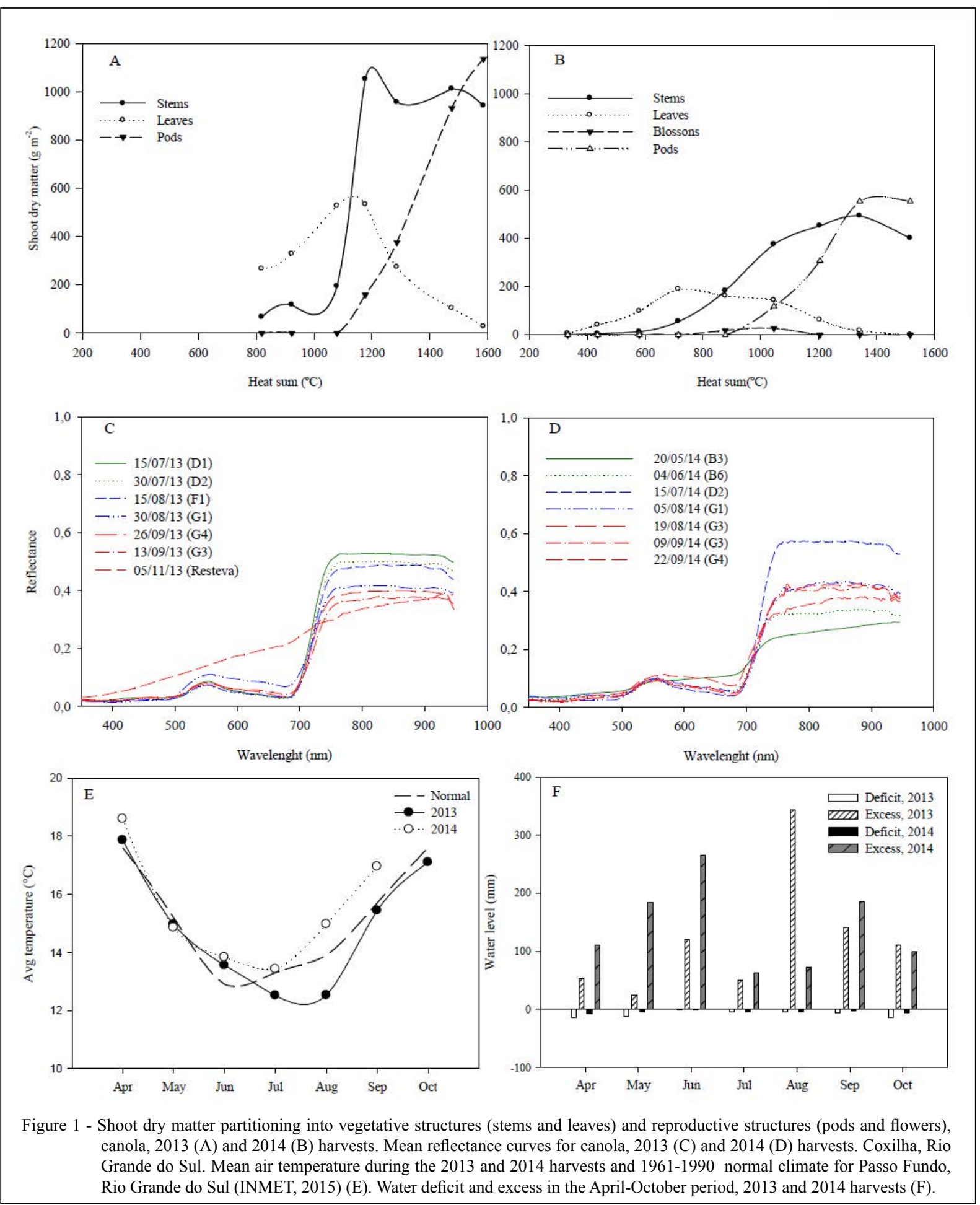

radiation is absorbed by leaves; $40-60 \%$ is reflected, and the rest is conveyed to the lower layers of the canopy (PONSONI, 2012).

Near-infrared reflectance is determined by the inner structural features of leaves, the structural organization of the spongy mesophyll, and the ratio of cells to air spaces within this tissue. Young leaves contain more air spaces, and thus have a structure conducive to near-infrared reflectance. As leaves senesce, number of air spaces decreased 
due to the presence of larger cells; thus, reducing reflectance in the near-infrared region (GATES et al., 1965).

Electromagnetic radiation (EMR) reflectance in the visible range increased approximately $44 \%$ from first measurement to its peak on 30 August 2013. At this time, plants were in full bloom, bearing yellow blossoms, thus showing that peak reflectance in the visible spectrum was achieved at the yellow wavelength. During the ripening stage, on measurements performed on 13 September and 26 September, canopy reflectance in the visible region was reduced (approximately 37\%). This occurred as photosynthetically active radiation (PAR) is intercepted and absorbed by pods and stems after blossoms have fallen off. According to NIED (2013), in canola, reproductive tissues and stems may account for up to $80 \%$ of all PAR intercepted by the canopy.

During the 2014 harvest, considering the same growth cycle stages, a EMR reflectance in the visible and near-infrared regions followed a similar pattern to 2013 harvest. In both years, maximum near-infrared reflectance occurred during the stem elongation stage (D1 and D2), whereas maximum visible reflectance coincided with the flowering stage (G1).

The vegetation indices employed in this study exhibited similar variation in temporal dynamics, demonstrating structural changes in the canopy (Figure 2). Values increased during vegetative plant development and peaked before the onset of flowering. Indices then declined during the flowering period. As discussed above, blossoms reflect part of the visible-range EMR incident onto the canopy. As most vegetation indices are based on the contrast between near-infrared and visible bands (Figure 1C1D), increased reflectance in the visible region due to flowering led to a reduction in vegetation indices. After the flowering period, vegetation index values rose again as blossoms dropped and pods began to form. Pods and stems absorb visible EMR to carry out photosynthesis from the seed-filling through the ripening stages (NIED, 2013).

This temporal pattern of variation in canola vegetation indices, with two peaks, is distinct from that observed in other crops. Annual crops usually display only one peak for vegetation indices (KLERING et al., 2013; JUNGES et al., 2013). This is useful information, as it may be used to distinguish canola crops in satellite imagery-based crop monitoring and mapping studies.

Comparison of results between the two years in which the experiment was conducted revealed the influence of weather conditions on plant growth. In 2014, vegetation indices also declined during the flowering period, although less sharply than in 2013. This may have been associated with the presence of fewer blossoms in the canopy during the 2014 harvest, leading to lower reflectance in the visible spectrum. Furthermore, at the end of the flowering period, the increase in vegetation index values was smaller, as, given the smaller number of blossoms in the canopy, there were fewer buds. Corroborating this hypothesis, the maximum pod dry-matter weight was $1,268 \mathrm{~g} \mathrm{~m}^{-2}$ in the 2013 harvest, versus $633 \mathrm{~g} \mathrm{~m}^{-2}$ in the 2014 harvest (Figure $1 \mathrm{~A}$ and $1 \mathrm{~B})$.

Regarding the variability attributable to nitrogen fertilization (Table 1), during the 2013 harvest, despite significant differences in the SR index across nitrogen treatments, the expected response pattern -;i.e., higher nitrogen doses being associated with higher vegetation indices - was not seen. In this harvest, the SR was the only index that revealed significant differences across nitrogen doses; the highest SR indices were reported for the $10 \mathrm{~kg} \mathrm{ha} \mathrm{a}^{-1}$ treatment during the flowering stage and for the $40 \mathrm{~kg} \mathrm{ha}^{-1}$ treatment during the ripening stage. During the 2014 harvest, significant differences in the calculated indices were observed only during the vegetative period and for NDVI and GNDVI. In terms of NDVI, plots that received the $160 \mathrm{~kg} \mathrm{ha}^{-1}$ treatment performed better than those treated with $80 \mathrm{~kg} \mathrm{ha}^{-1}$. In terms of GNDVI, plots that received the $160 \mathrm{~kg}$ $\mathrm{ha}^{-1}$ treatment performed better than those treated with $10 \mathrm{~kg} \mathrm{ha}^{-1}$.

These findings suggested that, in years most appropriate weather conditions to canola growth and development, as was the case in 2013, the sensor-based indices were less able to detect structural differences in the canola canopy between treatments. In years when weather conditions are less suitable for canola growth and development, as in 2014, the sensor was able to detect differences in the canopy across different nitrogen fertilization treatments. Of the vegetation indices employed in this study, those most sensitive in terms of ability to detect differences in the canola canopy across nitrogen fertilization treatments were the SR, NDVI, and GNDVI.

\section{CONCLUSION}

Changes in the spectral reflectance curves of canola occur largely in response to morphological 

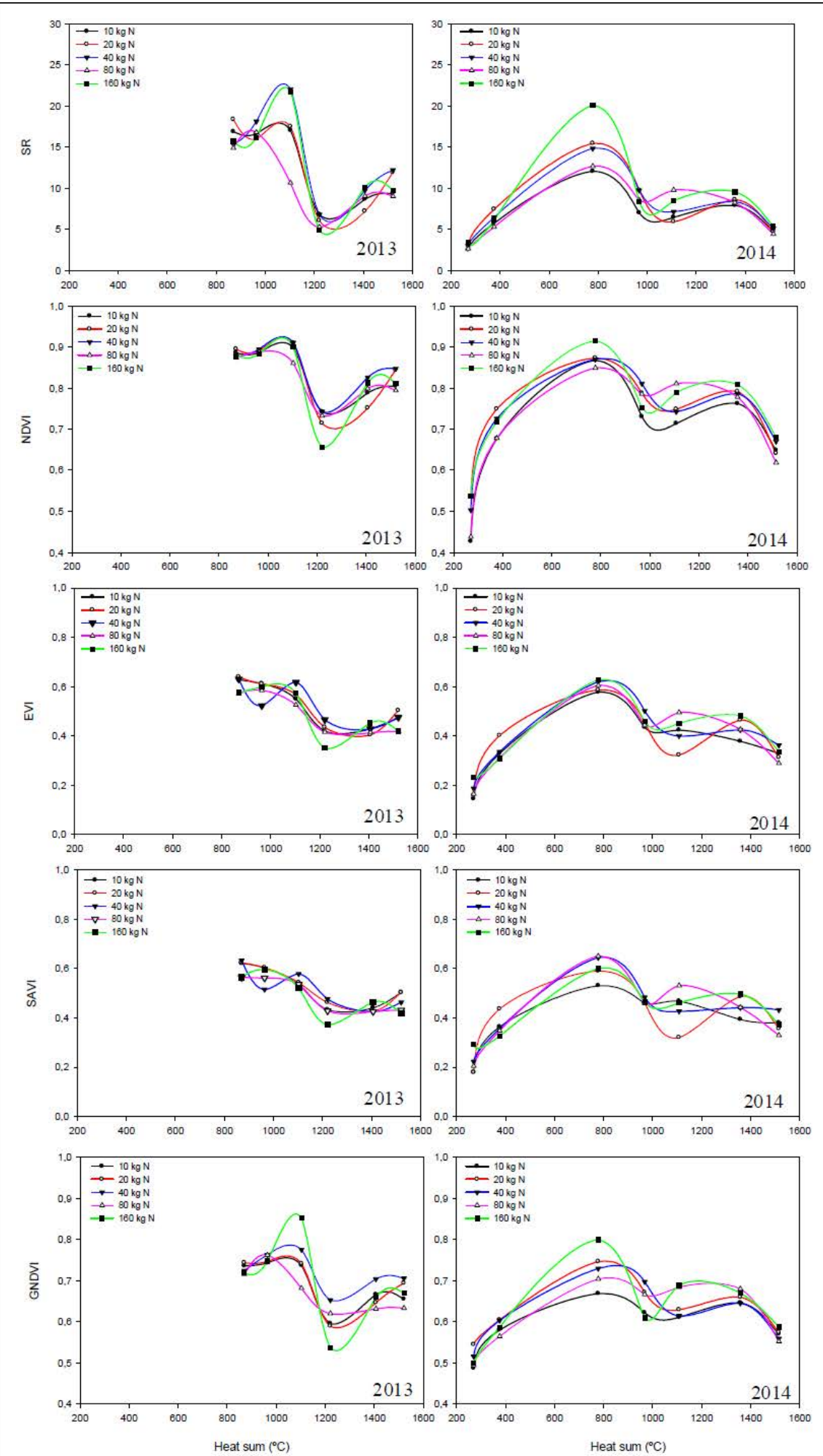

Figure 2 - Temporal dynamics of vegetation indices in canola (simple ratio [SR] normalized difference vegetation index [NDVI], enhanced vegetation index [EVI], soil-adjusted vegetation index [SAVI], and green normalized difference vegetation index [GNDVI]) as a function of heat sums across five doses of nitrogen top dress $(10,20,40,80$ and 160kg ha-1), 2013-2014. Coxilha, Rio Grande do Sul. 
Table 1 - Vegetation indices in canola (simple ratio [SR] normalized difference vegetation index [NDVI], enhanced vegetation index [EVI], soil-adjusted vegetation index [SAVI], and green normalized difference vegetation index [GNDVI]), across five doses of nitrogen top dress $\left(10,20,40,80\right.$ and $\left.160 \mathrm{~kg} \mathrm{ha}^{-1}\right)$, at three growth cycle stages: vegetative (Veg), flowering (Flo), and ripening (Rip). during the 2013 and 2014 harvests. Coxilha, Rio Grande do Sul.

\begin{tabular}{|c|c|c|c|c|c|c|c|}
\hline & Vegetation & Growth & ------------. & ---------Nit & en dose $(k$ & )--------- & ------------- \\
\hline Year & Index & Stage & 10 & 20 & 40 & 80 & 160 \\
\hline \multirow{15}{*}{2013} & \multirow{4}{*}{ SR } & Veg & $16.63 \mathrm{~A}$ & $15.99 \mathrm{~A}$ & $23.46 \mathrm{~A}$ & $16.78 \mathrm{~A}$ & $16.19 \mathrm{~A}$ \\
\hline & & Flo & $6.80 \mathrm{~A}$ & $6.04 \mathrm{AB}$ & $6.78 \mathrm{AB}$ & $7.35 \mathrm{AB}$ & $4.89 \mathrm{~B}$ \\
\hline & & Rip & $9.32 \mathrm{AB}$ & $11.91 \mathrm{AB}$ & $12.20 \mathrm{~A}$ & $9.00 \mathrm{~B}$ & $9.75 \mathrm{AB}$ \\
\hline & & Veg & $0.89 \mathrm{~A}$ & $0.89 \mathrm{~A}$ & $0.89 \mathrm{~A}$ & $0.89 \mathrm{~A}$ & $0.88 \mathrm{~A}$ \\
\hline & \multirow[t]{3}{*}{ NDVI } & Flo & $0.74 \mathrm{~A}$ & $0.71 \mathrm{~A}$ & $0.74 \mathrm{~A}$ & $0.73 \mathrm{~A}$ & $0.66 \mathrm{~A}$ \\
\hline & & Rip & $0.80 \mathrm{~A}$ & $0.84 \mathrm{~A}$ & $0.85 \mathrm{~A}$ & $0.79 \mathrm{~A}$ & $0.81 \mathrm{~A}$ \\
\hline & & Veg & $0.61 \mathrm{~A}$ & $0.61 \mathrm{~A}$ & $0.52 \mathrm{~A}$ & $0.58 \mathrm{~A}$ & $0.60 \mathrm{~A}$ \\
\hline & \multirow[t]{3}{*}{ EVI } & Flo & $0.42 \mathrm{~A}$ & $0.43 \mathrm{~A}$ & $0.47 \mathrm{~A}$ & $0.42 \mathrm{~A}$ & $0.35 \mathrm{~A}$ \\
\hline & & Rip & $0.47 \mathrm{~A}$ & $0.50 \mathrm{~A}$ & $0.48 \mathrm{~A}$ & $0.42 \mathrm{~A}$ & $0.42 \mathrm{~A}$ \\
\hline & & Veg & $0.60 \mathrm{~A}$ & $0.60 \mathrm{~A}$ & $0.48 \mathrm{~A}$ & $0.56 \mathrm{~A}$ & $0.59 \mathrm{~A}$ \\
\hline & \multirow[t]{3}{*}{ SAVI } & Flo & $0.43 \mathrm{~A}$ & $0.46 \mathrm{~A}$ & $0.48 \mathrm{~A}$ & $0.43 \mathrm{~A}$ & $0.37 \mathrm{~A}$ \\
\hline & & Rip & $0.50 \mathrm{~A}$ & $0.50 \mathrm{~A}$ & $0.46 \mathrm{~A}$ & $0.43 \mathrm{~A}$ & $0.42 \mathrm{~A}$ \\
\hline & & Veg. & $0.74 \mathrm{~A}$ & $0.75 \mathrm{~A}$ & $0.79 \mathrm{~A}$ & $0.76 \mathrm{~A}$ & $0.75 \mathrm{~A}$ \\
\hline & \multirow[t]{3}{*}{ GNDVI } & Flo & $0.60 \mathrm{~A}$ & $0.59 \mathrm{~A}$ & $0.65 \mathrm{~A}$ & $0.62 \mathrm{~A}$ & $0.54 \mathrm{~A}$ \\
\hline & & Rip & $0.65 \mathrm{~A}$ & $0.69 \mathrm{~A}$ & $0.71 \mathrm{~A}$ & $0.63 \mathrm{~A}$ & $0.67 \mathrm{~A}$ \\
\hline \multirow{15}{*}{2014} & & Veg. & $12.06 \mathrm{~A}$ & $15.44 \mathrm{~A}$ & $14.83 \mathrm{~A}$ & $12.67 \mathrm{~A}$ & $23.63 \mathrm{~A}$ \\
\hline & \multirow[t]{3}{*}{ SR } & Flo & $7.00 \mathrm{~A}$ & $9.75 \mathrm{~A}$ & $12.72 \mathrm{~A}$ & $8.54 \mathrm{~A}$ & $8.39 \mathrm{~A}$ \\
\hline & & Rip & $7.90 \mathrm{~A}$ & $8.59 \mathrm{~A}$ & $8.35 \mathrm{~A}$ & $8.24 \mathrm{~A}$ & $9.54 \mathrm{~A}$ \\
\hline & & Veg. & $0.87 \mathrm{AB}$ & $0.87 \mathrm{AB}$ & $0.87 \mathrm{AB}$ & $0.85 \mathrm{~B}$ & $0.91 \mathrm{~A}$ \\
\hline & \multirow[t]{3}{*}{ NDVI } & Flo & $0.73 \mathrm{~A}$ & $0.79 \mathrm{~A}$ & $0.81 \mathrm{~A}$ & $0.79 \mathrm{~A}$ & $0.75 \mathrm{~A}$ \\
\hline & & Rip & $0.76 \mathrm{~A}$ & $0.79 \mathrm{~A}$ & $0.79 \mathrm{~A}$ & $0.78 \mathrm{~A}$ & $0.81 \mathrm{~A}$ \\
\hline & & Veg. & $0.51 \mathrm{~A}$ & $0.59 \mathrm{~A}$ & $0.62 \mathrm{~A}$ & $0.60 \mathrm{~A}$ & $0.63 \mathrm{~A}$ \\
\hline & \multirow[t]{3}{*}{ EVI } & Flo & $0.43 \mathrm{~A}$ & $0.45 \mathrm{~A}$ & $0.50 \mathrm{~A}$ & $0.44 \mathrm{~A}$ & $0.46 \mathrm{~A}$ \\
\hline & & Rip & $0.38 \mathrm{~A}$ & $0.46 \mathrm{~A}$ & $0.42 \mathrm{~A}$ & $0.43 \mathrm{~A}$ & $0.48 \mathrm{~A}$ \\
\hline & & Veg & $0.53 \mathrm{~A}$ & $0.59 \mathrm{~A}$ & $0.64 \mathrm{~A}$ & $0.65 \mathrm{~A}$ & $0.60 \mathrm{~A}$ \\
\hline & \multirow[t]{3}{*}{ SAVI } & Flo & $0.46 \mathrm{~A}$ & $0.46 \mathrm{~A}$ & $0.48 \mathrm{~A}$ & $0.46 \mathrm{~A}$ & $0.46 \mathrm{~A}$ \\
\hline & & Rip & $0.39 \mathrm{~A}$ & $0.49 \mathrm{~A}$ & $0.44 \mathrm{~A}$ & $0.44 \mathrm{~A}$ & $0.50 \mathrm{~A}$ \\
\hline & & Veg & $0.67 \mathrm{~B}$ & $0.75 \mathrm{AB}$ & $0.73 \mathrm{AB}$ & $0.70 \mathrm{AB}$ & $0.80 \mathrm{~A}$ \\
\hline & \multirow[t]{2}{*}{ GNDVI } & Flo & $0.62 \mathrm{~A}$ & $0.67 \mathrm{~A}$ & $0.70 \mathrm{~A}$ & $0.67 \mathrm{~A}$ & $0.61 \mathrm{~A}$ \\
\hline & & Rip & $0.65 \mathrm{~A}$ & $0.66 \mathrm{~A}$ & $0.64 \mathrm{~A}$ & $0.65 \mathrm{~A}$ & $0.67 \mathrm{~A}$ \\
\hline
\end{tabular}

( $\left.{ }^{*}\right)$ Means followed by the same letter on row are not statistically different.

changes in the canopy that took place during the various stages of the growth cycle and to associated weather conditions. Temporal profile of vegetation indices in canola displays two maximum peaks, one before flowering and the other after flowering, which makes canola easy to distinguish from other crops grown in Southern Brazil. The SR, NDVI, and GNDVI vegetation indices are sensitive metrics for detection of changes in the spectral reflectance of canola associated with variation in top dress nitrogen application.

\section{ACKNOWLEDGEMENTS}

The authors thank Universidade Federal do Rio Grande do Sul (UFRGS), EMBRAPA Trigo, and Conselho Nacional de Desenvolvimento Científico e Tecnológico (CNPq) for supporting the conduction of this study. 


\section{REFERENCES}

ANDERSON, L.O. et al. Sensor MODIS: uma abordagem geral. São José dos Campos: INPE, 2003. Available from: < https://www. researchgate.net/profile/Liana_Anderson/publication/268337770 SENSOR MODIS UMA ABORDAGEM GERAL links $/ 55787 \overline{8} \mathrm{~d} 508$ aeb6 $\overline{\mathrm{d}} 8 \mathrm{c} 01 \mathrm{f16} \overline{7}$.pdf $>$. Accessed: Mar. 30, 2016.

GATES, D.M. et al. Spectral properties of plants. Applied Optics, v.4, n.1, p.11-20, (1965).

GITELSON, A.A. et al. Use of a green channel in remote sensing of global vegetation from EOS-MODIS. Remote Sensing of Environment, v.58, n.3, p.289-298, 1996. Available from: $<$ http:// dx.doi.org/10.1016/S0034-4257(96)00072-7>. Accessed: Sep. 15, 2015. doi: 10.1016/S0034-4257(96)00072-7.

GRANT, C.A.; BAILEY, L.D. Fertility management in canola production. Canadian Journal of Plant Science, v.73, p.651-670, 1993. Available from: <http://dx.doi.org/10.4141/cjps93-087>. Accessed: Jul. 07, 2015. doi: 10.4141/cjps93-087.

HUETE, A.R. A soil-adjusted vegetation index (SAVI). Remote Sensing of Environment, v.25, p.295-309, 1988. Available from: $<$ http://dx.doi.org/10.1016/0034-4257(88)90106-X>. Accessed: Aug. 23, 2015. doi: 10.1016/0034-4257(88)90106-X.

IRIARTE, L.B.; VALETTI, O.E. Cultivo de colza. Buenos Aires: Instituto Nacional de Tecnologia Agropecuária - INTA, 2008. 156p.

JENSEN, J.R. Sensoriamento remoto do ambiente: uma perspectiva em recursos terrestres. 2.ed. São José dos Campos: Parêntese, 2009. 598p.

JORDAN, C.F. Derivation of leaf area index from quality of light on the forest floor. Ecology, v.50, p.663-666, 1969. doi: $10.2307 / 1936256$.

JUNGES, A.H. et al. Identification of croplands of winter cereals in Rio Grande do Sul state, Brazil, through unsupervised classification of normalized difference vegetation index images. Engenharia Agrícola, v.33, n.4, p.883-895, 2013. Available from: <http:// dx.doi.org/10.1590/S0100-69162013000400027>. Accessed: Sep. 02, 2015. doi: 10.1590/S0100-69162013000400027.

JUSTES, E. et al. Effect of crop nitrogen status and temperature on the radiation use efficiency of winter oilseed rape. European Journal of Agronomy, v.13, p.165-177, 2000. Available from: $<$ http://dx.doi.org/10.1016/S1161-0301(00)00072-1>. Accessed: Aug. 14, 2015. doi: 10.1016/S1161-0301(00)00072-1.

JUSTICE, C.O. et al. The moderate resolution imaging spectroradiometer (Modis): land remote sensing for global change research. IEEE Transactions on Geoscience and Remote Sensing, v.36, n.4, p.1228-1249, 1998. Available from: <http:// dx.doi.org/10.1109/36.701075>. Accessed: Jun. 23, 2015. doi: $10.1109 / 36.701075$.

KLERING, E.V. Influência do fenômeno ENOS nos perfis temporais de NDVI das áreas orizícolas do Rio Grande do Sul. 2013. Ciência e Natura, v. Dez, p.94-96, 2013. Available from: $<$ http://dx.doi.org/10.5902/2179-460X11561>. Accessed: Jul. 31, 2015. doi: 10.5902/2179-460X11561.

MÜLLER, K. et al. Analyses of vegetation indices derived from hyperspectral reflection measurements for estimating crop canopy parameters of oilseed rape (Brassica napus L.). Biosystems Engineering, v.101, p.172-182, 2008. Available from: <http:// dx.doi.org/10.1016/j.biosystemseng.2008.07.004> . Accessed: Apr. 26, 2015. doi: 10.1016/j.biosystemseng.2008.07.004

NIED, A.H. Parâmetros bioclimáticos e resposta da canola ao ambiente físico. 2013. 135f. Tese (Doutorado em que Fitotecnia) - Programa de Pós-graduação em Fitotecnia, Faculdade de Agronomia, Universidade Federal do Rio Grande do Sul, Porto Alegre, RS.

OMETTO, A.C. Bioclimatologia vegetal. São Paulo: Agronômica Ceres, 1981. 440p.

PONZONI, F.J. et al. Sensoriamento remoto da vegetação. 2 ed. Cubatão: Oficina de Textos, 2012. 160p.

RAPACZ, M. Frost resistance and cold acclimatation abilities of spring-type oilseed rape. Plant Science, v.147, p.55-64, 1999

ROUSE, J.W. et al. Monitoring vegetation systems in the great plains with ERTS. In: EATHRESOURSES TECHNOLOGY SATELLITE - 1 SYMPOSIUM, 3., 1973, Washington. Proceedings... Washington: ERTS, 1973. V.1, sec A, p.309-317.

SENTELHAS, P.C.O. Introdução. In: MONTEIRO, J.E.B.A. (Coord.). Agrometeorologia dos cultivos: o fator meteorológico na produção agrícola. Brasília: INMET, 2009. p.3-12.

STRECK, E.V. et al. Solos do Rio Grande do Sul. Porto Alegre: EMATER/RS; UFRGS, 2002. 126p.

THORNTHWAITE, C.W.; MATHER, J.R. The water balance. Publication of climatology, v.8, 104p, 1955

TOMM, G.O. Indicativos tecnológicos para a produção de canola no Rio Grande do Sul. Passo Fundo: Embrapa Trigo, 2007. 32p. (Embrapa Trigo. Sistema de produção, 4). Available from: <http://www.cnpt.embrapa.br/culturas/canola/p sp03 2007. pdf $>$. Accessed: Sept. 25, 2015. 